\title{
Pemekaran Nagari Padang Limau Sundai Kecamatan Sangir Jujuan Kabupaten Sol ok Selatan
}

\author{
Netrivianti \\ Universitas Ekasakti Padang
}

\begin{abstract}
A bstract
Base umpteen acquired research yielding. First, marginally, $\mathrm{N}$ agari's unfoldment Padang Limau Sundai is base to Section 15 sentences (1 ), (2) and (3) Province Region regulations Number West Sumatras 9 Years 2000 about Governance Subject rule Nagari, are next to be substituted by $\mathrm{N}$ umber Region regulation 08 Y ears 2007 about Governance Nagari whereabouts said that (1) In Order To Commanding management effectivenesses $\mathrm{N}$ agari and step-up $\mathrm{N}$ agari's society welfare, to region Nagari can do nagari's unfoldment, (2) N agari's U nfoldments is done through deliberation mufakat with paying attention custom perfection and local culture social and congruity its society, (3) Nagari's unfoldment Procedure is managed in Regency Region regulation. Secand, Constraint in $\mathrm{N}$ agari's unfoldment Padang Limau Sundai's Sangir Jujuan's district south Solok Regency, which is marks sense pros and cons, mark sense that assumption region unfoldment as ketertinggalan's cause, about problem reducing the fund, its happening is conflicting, SDM'S low and supporting and reducing facility its society participation. Third, effort that is done in order to settle $\mathrm{N}$ agari's unfoldment constraint Padang Limau Sundai Sangir Jujuan's district South Solok Regency, which is do reregion study unfoldment preparation, increasing civil society role, doing procedural fix, and increases facility and peripheral welfarestep-up nagari.
\end{abstract}

\section{Pendahuluan}

Memasuki akhir dekade 1990-an Indonesia mengalami perubahan sosial politik yang bermuara kepada pilihan melaksanakan desentralisasi sebagai salah satu modal utama pembangunan Indonesia. Hal ini ditandai dengan pemberlakuan Undang-Undang Nomor 32 Tahun 2004 tentang Pemerintahan Daerah. Rencana Pembangunan Jangka Menengah Nasional (RPJMN) 2004-2009 menempatkan revitalisasi proses desentralisasi dan otonomi daerah ini sebagai satu prioritas dalam pembangunan nasional. Revitalisasi tersebut diarahkan dalam rangka untuk:

a. Memperjelas pembagian kewenangan antar tingkat pemerintahan;

b. Mendorong kerjasama antar pemerintah daerah;

c. Menata kelembagaan pemerintah daerah agar lebih efektif dan efisien;

d. meningkatkan kualitas aparatur pemerintah daerah;

e. Meningkatkan kapasitas keuangan pemerintah daerah; serta

f. Menata Daerah Otonom Baru (DOB).

Semangat otonomi daerah itu sendiri salah satunya bermuara kepada keinginan daerah untuk memekarkan diri yang kemudian diatur dalam Peraturan Pemerintah Nomor 129 Tahun 2000 tentang Persyaratan Pembentukan, dan Kriteria Pemekaran, Penghapusan dan Penggabungan Daerah. Dalam prakteknya, pemekaran daerah jauh lebih mendapat perhatian dibandingkan penghapusan ataupun penggabungan daerah. 
Dalam Peraturan Pemerintah tersebut, daerah berhak mengajukan usulan pemekaran terhadap daerahnya selama telah memenuhi syarat teknis, administratif, dan fisik dengan tujuan untuk mensejahterakan masyarakat yang ada di wilayahnya.

Sejak kebijakan otonomi daerah di Indonesia dicanangkan banyak daerah-daerah yang cenderung untuk melaksanakan pemekaran wilayah. Peluang secara normatif untuk melakukan pemekaran wilayah atau pembentukan suatu daerah baru dapat dilaksanakan sepanjang mengikuti prosedur dan mekanisme yang berlaku. Dalam rangka memberikan payung hukum terhadap kebijakan pemekaran wilayah, maka pemerintah mengeluarkan beberapa peraturan seperti PP No. 129 Tahun 2000 tentang Pengaturan Persyaratan Pembentukan dan Kriteria Pemekaran, Penghapusan, dan Penggabungan Daerah yang diikuti dengan UU No. 32 Tahun 2004 tentang Pemerintahan Daerah. Pembentukan suatu daerah otonomi baru dimungkinkan jika memenuhi syarat-syarat kemampuan ekonomi, potensi daerah, sosial budaya, sosial politik, jumlah penduduk, luas daerah, dan pertimbangan lain yang memungkinkan terselenggaranya otonomi daerah.

Dalam rangka pemekaran wilayah tentunya perlu mempertimbangkan beberapa aspek seperti fungsi wilayah, kriteria fisik/ lingkungan, ekonomi, dan sosial. Pertimbangan pemekaran wilayah tersebut untuk menghindari agar tidak terjadi disparitas pada wilayah yang dimekarkan maupun wilayah hasil pemekaran. Adapun manfaat dasar pertimbangan tersebut adalah sebagai berikut:

1. Pertimbangan fungsi wilayah digunakan untuk mengetahui tingkat keseimbangan antara pusat-pusat pelayanan yang ada dan distribusi penduduk di dalam masing-masing kecamatan pada wilayah administrasi suatu Kabupaten/ Kota.

2. Pertimbangan kriteria fisik/ lingkungan diperlukan untuk menilai potensi lahan dan ketersediaan sumber daya lahan dalam kaitannya terhadap pembagian wilayah pemekaran yang bertujuan agar masing-masing wilayah hasil pemekaran dapat tumbuh dan berkembang.

3. Pertimbangan kriteria ekonomi diperlukan untuk mengetahui potansi ekonomi masing-masing wilayah pemekaran. Wilayah induk maupun wilayah-wilayah hasil pemekaran diharapkan mampu berperan sebagai pusat penggerak pertumbuhan ekonomi bagi daerah sekitarnya, guna meningkatkan kegiatan ekonomi baru, dan pendapatan yang lebih baik bagi masyarakat untuk memperbaiki kesejahteraannya.

4. Pertimbangan kriteria sosial diperlukan untuk mengetahui tentang kendali antar kecamatan, interaksi, dan aktivitas masyarakat. Bertujuan agar kecamatan yang jauh dari jangkauan fasilitas pelayanan dan pusat pemerintahan dapat diatasi dengan adanya wilayah administratif baru.

Dalam satu dekade terakhir, gejala pemekaran daerah terus terjadi sehingga jumlah daerah otonom di Indonesia bertambah hampir seratus persen. Di banyak kasus, kebijakan pembentukan daerah baru ini merupakan solusi bagi permasalahan publik di daerah maupun nasional. Namun di 
banyak kasus, kebijakan tersebut menimbulkan perumitan problema dalam pemerintahan, berbangsa dan bernegara.

Kecamatan Sangir Jujuan sebagai salah satu kecamatan di Kabupaten Solok Selatan yang merupakan hasil pemekaran Kabupaten Solok tahun 2001. Sedangkan Kecamatan Sangir Jujuan saat itu terdiri dari 3 (tiga) Nagari, yaitu Nagari Lubuk Malako, Nagari Bidar Alam dan Nagari Sungai Kunyit. Sedangkan pada bulan Juli tahun 2007 terjadi lagi pemekaran Kecamatan Sangir Jujuan menjadi 2 (dua) Kecamatan, yaitu Kecamatan Sangir Jujuan (Kecamatan Induk) dan Kecamatan Sangir Balai Janggo.

Kecamatan Sangir Jujuan ini pada awalnya terdiri dari 4 (empat) Nagari, setelah adanya pemekaran pada bulan April 2009, maka jumlah nagari menjadi 5 (lima) nagari, yaitu Nagari Padang Air Dingin, Lubuk Malako, Padang Ganting, Bidar A lam dan Padang Limau Sundai serta terdiri dari 23 Jorong dengan luas $326 \mathrm{Km}^{2}$, letak kecamatan yang membentang dari utara ke selatan berada pada daerah perbukitan rendah dialiri oleh 2 (dua) sungai besar.

Nagari Padang Limau Sundai yang merupakan nagari hasil pemekaran pada tahun 2009 dengan jumlah penduduk sebanyak 1.032 jiwa, sarana kesehatan berupa posyandu sebanyak 3 (tiga) buah, Sekolah Dasar Negeri sebanyak 1 (satu) buah. Dengan demikian, jelas bahwa Nagari Padang Limau Sundai merupakan nagari yang relatif muda dengan jumlah sarana dan prasarana yang masih terbatas karena merupakan nagari hasil pemekaran.

\section{Rumusan Masalah}

1. Bagaimana proses pemekaran Nagari Padang Limau Sundai Kecamatan Sangir Jujuan Kabupaten Solok Selatan?

2. A pa saja yang menjadi kendala dalam pemekaran Nagari Padang Limau Sundai Kecamatan Sangir Jujuan Kabupaten Solok Selatan?

3. A pa saja upaya-upaya yang dilakukan dalam rangka mengatasi kendala pemekaran Nagari Padang Limau Sundai Kecamatan Sangir Jujuan Kabupaten Solok Selatan?

Tujuan Penelitian

1. Untuk mengetahui proses pemekaran Nagari Padang Limau Sundai Kecamatan Sangir Jujuan Kabupaten Solok Selatan;

2. Untuk mengetahui kendala-kendala yang ditemui dalam pemekaran Nagari Padang Limau Sundai Kecamatan Sangir Jujuan Kabupaten Solok Selatan;

3. Untuk mengetahui upaya-upaya yang dilakukan dalam rangka mengatasi kendala dalam pemekaran Nagari Padang Limau Sundai Kecamatan Sangir Jujuan Kabupaten Solok Selatan.

II. Metodologi Penelitian Metode yang Digunakan

Dalam penelitian ini penulis menggunakan metode deskriptif kualitatif, di mana dalam penelitian yang bersifat deskriptif kualitiatif ini 
prosedur sampling yang terpenting adalah bagaimana menentukan informan kunci (key informan) yang sarat informasi sesuai dengan fokus penelitian. Mengingat dasar penelitian ini bersifat studi kasus, sehingga metode pengumpulan data akan lebih banyak diadakan dengan wawancara mendalam (indepth interview) dengan informan (informan) yang terpilih.

\section{Populasi dan Sampel}

Populasi dalam penelitian ini adalah Camat Sangir Jujuan, Wali Nagari Padang Limau Sundai, seluruh pegawai di Kantor Camat Sangir Jujuan dan Kantor Walinagari Padang Limau Sundai dan tokoh masyarakat di Nagari Padang Limau Sundai Kecamatan Sangir Jujuan Kabupaten Solok Selatan. Sedangkan sampelnya adalah sebanyak 9 (sembilan) orang hal ini diambil berdasarkan tingkat heterogenitasnya dengan menggunakan teknik penentuan sampel berupa teknik purposive sampling.

\section{Analisis Data}

Analisis data yang digunakan dalam penelitian ini adalah analisis kualitatif deskriptif, untuk melihat tanggapan informan dalam menarik suatu pernyataan yang mendukung dari pemahaman atas keadaan yang sebenarnya. Selanjutnya semua data yang diperoleh kemudian dikumpulkan, lalu dipilih dan diklasifikasi sesuai dengan pokok-pokok permasalahan yang hendak dibahas, sehingga data relevan dan kemudian diinterprestasikan serta analisis untuk diambil kesimpulan.

\section{Hasil Penelitian dan Pembahasan}

Secara teritorial, pada umumnya wilayah nagari lebih besar dari desa yang ada, bahkan ada sebuah nagari teritorialnya sama dengan teritorial kecamatan. Keanehan juga terjadi ketika sebuah nagari teritorialnya sama dengan dua kecamatan. Hal ini terjadi karena pada masa Orde baru tidak terjadi pemekaran nagari, karena tidak difungsikannya nagari sebagai organisasi pemerintahan. Sebaliknya, desa dan kecamatan sebagai organisasi pemerintahan dimekarkan dan dikembangkan terus. Akhirnya, ketika Peraturan Daerah tentang Pemerintahan Nagari terbit, maka pemekaran nagari adalah sebuah kebutuhan baru guna penertiban bahwa nagari adalah organisasi pemerintahan terkecil yang berada di bawah kecamatan, sifatnya otonom dan tidak bertanggung jawab kepada Camat, tetapi kepada Dewan Perwakilan A nak N agari.

Secara garis besar, pemekaran Nagari Padang Limau Sundai adalah berdasarkan kepada Pasal 15 ayat (1), (2) dan (3) Peraturan Daerah Propinsi Sumatera Barat N omor 9Tahun 2000 tentang Ketentuan Pokok Pemerintahan Nagari, yang kemudian diganti dengan Peraturan Daerah Nomor 08 Tahun 2007 tentang Pemerintahan Nagari di mana disebutkan bahwa:

(1) Dalam rangka efektivitas penyelenggaraan Pemerintah Nagari dan peningkatan kesejateraan masyarakat nagari, terhadap wilayah nagari dapat dilakukan pemekaran nagari; 
(2) Pemekaran nagari dilakukan melalui musyawarah mufakat dengan memperhatikan keutuhan adat dan sosial budaya setempat serta keharmonisan masyarakatnya;

(3) Tata cara pemekaran nagari diatur dalam Peraturan Daerah Kabupaten.

Pemekaran harus sesuai prosedur atau Undang-Undang yang berlaku. Pemekeran daerah diperbolehkan, asal mengikuti prosedur yang berlaku, karena harus menetukan langkah-langkah apa yang harus diambil serta kesiapan aparatur dalam melaksanakannya. Peraturan Daerah Nomor 08 Tahun 2007 tentang Pemerintahan Nagari sangat berpeluang untuk pemekaran Nagari dengan adanya aturan yang telah ditetapkan oleh masing-masing kabupaten.

Proses Pemekaran Nagari Padang Limau Sundai Kecamatan Sangir Jujuan Kabupaten Solok Selatan

Proses pemekaran Nagari Padang Limau Sundai yang merupakan hasil pemekaran dari nagari induk Bidar Alam tetap mengacu kepada Peraturan Daerah dan Peraturan Bupati Kabupaten Solok Selatan yang ada dan tetap menjunjung tinggi azas musyawarah dan mufakat. Di dalam musyawarah ini pun dibahas juga mengenai tapal batas antara nagari induk Bidar Alam dan nagari Padang Limau Sundai yang akan dimekarkan.

Tata cara pemekaran Nagari Padang Limau Sundai harus memenuhi beberapa persyaratan administratif, teknis, dan fisik kewilayahan, yaitu sebagai berikut:

1. Syarat administratif

a) Adanya prakarsa dan kesepakatan masyarakat Padang Limau Sundai untuk membentuk nagari; dan

b) Masyarakat Padang Limau Sundai mengajukan usul pembentukan nagari kepada BPN dan Wali Nagari.

2. Syarat teknis

Syarat teknis meliputi faktor kemampuan ekonomi, potensi daerah, sosial budaya, sosial politik, kependudukan, luas daerah, pertahanan, keamanan, kemampuan keuangan, tingkat kesejahteraan masyarakat, dan rentang kendali penyelenggaraan pemerintahan daerah.

Syarat pemekaran nagari Padang Limau Sundai secara teknis sudah memenuhi syarat, yaitu sebagai berikut:

a) Nagari Padang Limau Sundai yang saat ini mempunyai jumlah penduduk sebanyak 1.809 jiwa yang tersebar dalam 4 (empat) jorong, di mana sebelum terjadinya pemekaran dengan nagari induk adalah sebanyak 3503 jiwa. Jika mengacu pada Pasal 5 Peraturan Daerah Kabupaten Solok Selatan Nomor 4 Tahun 2005 tentang Pemerintahan Nagari jumlah penduduk nagari yang akan dimekarkan adalah berjumlah paling sedikit 2.500 (Dua ribu lima ratus) jiwa, kecuali daerahdaerah yang karena kondisi geografisnya dipandang perlu untuk dimekarkan. Hal ini sudah memenuhi kriteria untuk dilakukan pemekaran;

b) Luas daerah nagari Padang Limau Sundai adalah 113.347 hektar. Berdasarkan Pasal 5 Peraturan Daerah Kabupaten Solok Selatan Nomor 4 
Tahun 2005 tentang Pemerintahan Nagari bahwa luas wilayah terjangkau secara berdaya guna untuk memberikan pelayanan kepada masyarakat dan memungkinkan untuk dilakukan komunikasi antar jorong yang ada. Hal ini sudah memenuhi kriteria;

c) Sarana dan prasarana nagari Padang Limau Sundai terdiri dari Balai Nagari di Nagari Padang Limau Sundai sebanyak 1 (satu) buah, jalan kabupaten belum ada, jalan kecamatan sepanjang 4 (empat) kilometer, jalan nagari sepanjang $13 \mathrm{Km}$ dan masjid sebanyak 5 (lima) buah. Jika mengacu pada Pasal 5 Peraturan Daerah Kabupaten Solok Selatan Nomor 4 Tahun 2005 tentang Pemerintahan Nagari bahwa syarat pemekaran nagari adalah tersedianya sarana dan prasarana untuk sebuah nagari dan hal ini sudah memenuhi kriteria.

d) Mata pencaharian penduduk Nagari Padang Limau Sundai adalah sebagai petani, yaitu sebanyak 602 orang, pedagang sebanyak 200 orang, PNS sebanyak 4 (empat) orang dan buruh sebanyak 42 orang. Jika mengacu pada Pasal 5 Peraturan Daerah Kabupaten Solok Selatan Nomor 4 Tahun 2005 tentang Pemerintahan Nagari bahwa syarat pemekaran nagari adalah tersedianya sumber-sumber ekonomi untuk mata pencarian masyarakat. Hal ini juga sudah memenuhi kriteria.

3. Syarat fisik kewilayahan, yang meliputi:

a) Cakupan wilayah;

b) Lokasi calon ibukota; dan

c) Sarana dan prasarana pemerintahan.

Sarana dan prasarana pemerintahan sebagaimana meliputi bangunan dan lahan untuk kantor Wali Nagari yang dapat digunakan untuk memberikan pelayanan kepada masyarakat.

Untuk lebih jelasnya mengenai prosedur atau proses pemekaran

Kendala dalam Pemekaran Nagari Padang Limau Sundai Kecamatan Sangir Jujuan Kabupaten Solok Selatan

Pada umumnya, lima puluh persen dari pemekaran nagari yang terjadi di Kabupaten Solok Selatan, yaitu sejak tahun 2005 sudah terjadi 20 pemekaran nagari, termasuk pemekaran nagari Padang Limau Sundai yang merupakan hasil pemekaran nagari Bidar Alam yang terjadi pada tahun 2009 memiliki permasalahan utama adalam dalam segi infrastruktur dan roda pemerintahan yang kurang berjalan baik yang berdampak pada tidak maksimalnya pelayanan kepada masyarakat seperti masih adanya Wali Nagari yang berdomisili di nagari setempat. Padahal tujuan pemekaran nagari adalah untuk lebih meningkatkan pelayanan kepada masyarakat, mengakomodir dan mencarikan solusi permasalahan di masyarakat, dan meningkatkan taraf hidup masyarakat.

Adapun kendala yang ditemui dalam pemekaran Nagari Padang Limau Sundai Kecamatan Sangir Jujuan Kabupaten Solok Selatan adalah sebagai berikut:

1. Adanya Pro dan Kontra

Pada awalnya, setiap terjadi pemekaran daerah termasuk pemekaran Nagari Padang Limau Sundai akan melahirkan pro dan kontra. Artinya, akan 
ada pihak yang mendukung serta pihak yang menentang. Dengan telah diresmikannya nagari Padang Limau Sundai hasil pemekaran ini, pro-kontra yang terjadi pada sebagian masyarakat pada saat berlangsungnya proses pemekaran. Pihak yang mendukung dengan alasan bahwa dengan adanya pemekaran Nagari Padang Limau Sundai, maka akan semakin mudah dan dekatnya masyarakat dalam mengurus berbagai keperluan administrasi di kantor wali nagari, seperti mengurus surat-surat untuk kepe. Sementara itu, pihak yang kontra dengan alasan bahwa dengan adanya pemekaran Nagari Padang Limau Sundai akan merubah status nagari sebagai wilayah kesatuan masyarakat hukum adat dengan lembaga kerapatan adat nagari.

Dengan bertambahnya jumlah nagari di Kabupaten Solok Selatan ini, maka angka kemiskinan akan semakin berkurang pula. Sebab berdasarkan pendataan yang baru dilakukan oleh BPS Kabupaten Solok Selatan, ternyata penurunan angka kemiskinan di daerah ini sudah cukup membanggakan, yakni dari 42 persen pada tahun 2007 lalu, pada sensus 2010 yang lalu sudah menjadi 24 persen. Oleh karena itu, sumbangsih dengan adanya pemekaran Nagari Padang Limau Sundai, maka peran dari wali nagari sangat dibutuhkan, agar angka ini bisa mengalami penurunan lebih tinggi lagi di masa datang.

\section{Adanya Anggapan bahwa Pemekaran Daerah sebagai Penyebab Ketertinggalan}

Laksana pedang bermata dua. Pemekaran daerah sejatinya ditujukan dalam rangka menyelesaikan ketertinggalan, namun di pihak lain seringkali dituding menjadi penyebab bertambahnya jumlah daerah tertinggal. Malah ada yang menilai pemekaran daerah sebagai penyebab ketertinggalan itu sendiri. Kalau dinilai sebagai penyebab ketertinggalan barangkali tidak tepat. Tapi kalau dikatakan pemekaran daerah dapat menyebabkan bertambahnya jumlah nagari tertinggal, itu ada benarnya. Misalnya, satu daerah tertinggal dimekarkan menjadi tiga daerah otonom, maka secara administratif, jumlah daerah tertinggal menjadi tiga, yaitu satu daerah induk yang dari awalnya memang sudah tertinggal dan tambahan dua lagi dari daerah otonom baru. Namun demikian, dimekarkan ataupun tidak, dua wilayah yang menjadi daerah otonom baru tersebut tetap saja tertinggal. Hanya yang pasti, dengan pemekaran ini, kedua wilayah tersebut mempunyai peluang untuk lebih diperhatikan dan keluar dari ketertinggalan. Bagaimana tidak, dengan menjadi daerah otonom, maka pelayanan masyarakat menjadi lebih dekat dan memiliki anggaran yang dikelola sendiri yang dapat digunakan untuk membangun wilayah tersebut. Sewaktu bergabung dengan daerah induk, boleh jadi alokasi anggaran ke wilayah tersebut sangat kecil.

\section{Permasalahan Kurangnya Dana}

Permasalahan yang terjadi dalam rangka pemekaran Nagari Padang Limau Sundai adalah terkendala masalah dana atau anggaran meskipun pemekaran Nagari Padang Limau Sundai saat ini sudah terealisasi, sehingga 
Nagari Padang Limau Sundai yang terdapat di Kecamatan Sangir Jujuan ini pada awalnya terdiri dari 4 (empat) Nagari, setelah adanya pemekaran pada bulan A pril 2009, maka jumlah nagari menjadi 5 (lima) Nagari dan 23Jorong.

Penghentian kebijakan pemekaran nagari oleh Pemerintah Daerah Kabupaten Solok Selatan sementara ini bukanlah masalah nagari. Tapi masalah pemerintah daerah, karena pemerintah daerah tidak memiliki cukup dana. Kendati pemekaran nagari Padang Limau Sundai membuka peluang untuk menjadi sarana keluar dari ketertinggalan, namun dalam faktanya sekarang masih sulit diwujudkan karena berbagai persoalan yang menyelimuti nagari baru hasil pemekaran tersebut.

\section{Terjadinya Konflik}

Terjadinya berbagai konflik di masa transisi pasca pemekaran nagari Padang Limau Sundai telah menjauhkan atau paling tidak memperlambat tujuan pemekaran nagari. Di samping itu, ditemukan bahwa belum meningkatnya pelayanan kepada masyarakat di beberapa nagari baru hasil pemekaran di samping karena persoalan konflik tadi d iantaranya diakibatkan juga oleh persoalan kelembagaan, infrastruktur, dan Sumber Daya Manusia.

\section{Minimnya SDM dan Fasilitas Pendukung}

Minimnya SDM dan fasilitas pendukung yang kurang berjalan baik yang berdampak pada tidak maksimalnya pelayanan kepada masyarakat. Tujuan pemekaran nagari Padang Limau Sundai, untuk lebih meningkatkan pelayanan kepada masyarakat Padang Limau Sundai, mengakomodir dan mencarikan solusi permasalahan di masyarakat, dan meningkatkan taraf hidup masyarakat. Jika roda pemerintahan tidak berjalan baik, seperti Wali Nagari dan Ketua Badan Permusyawaratan Nagari (BPN) tidak berdomisili di tempatnya bertugas atau Wali Nagari dan BPN tidak menyamakan misi, maka bisa dipastikan roda pemerintahan nagari tersebut tidak berjalan optimal dan pelayanan masyakarat kurang maksimal karean masih memiliki permasalahan dalam segi infrastruktur dan roda pemerintahan.

\section{Kurangnya Partisipasi Masyarakat}

Agar implementasi kebijakan dalam pemekaran nagari Padang Limau Sundai dapat dilaksanakan dengan baik, maka diperhatikan faktorfaktor berikut ini, yaitu:

(1) Kondisi eksternal yang dihadapi organisasi dan instansi pelaksana tidak akan menimbulkan gangguan dan kendala;

(2) Untuk melaksanakan kebijakan harus tersedia waktu dan sumbersumber yang memadai;

(3) Keterpaduan antar sumber daya yaitu manusia, dana dan fasilitasfasilitas pendukung lainnya dengan melibatkan partisipasi masyarakat. Kurangnya partisipasi masyarakat akan berakibat pada tidak maksimalnya pemekaran nagari termasuk Nagari Padang Limau Sundai. 
Berdasarkan uraian di atas, maka proses pemekaran nagari Padang Limau Sundai dari nagari induk Bidar Alam pada tahun 2009 masih terdapat beberapa kendala sebagaimana diuraikan sebelumnya.

Upaya yang dilakukan dalam rangka mengatasi kendala pemekaran Nagari Padang Limau Sundai Kecamatan Sangir Jujuan Kabupaten Solok Selatan

Pemekaran Nagari Padang Limau Sundai dari nagari induk nagari Bidar Alam yang bertujuan untuk meningkatkan kesejahteraan masyarakat melalui peningkatan pelayanan kepada masyarakat, percepatan pertumbuhan kehidupan demokrasi, percepatan pelaksanaan pembangunan perekonomian daerah, percepatan pengelolaan potensi daerah, serta peningkatan keamanan dan ketertiban. Namun tidak semua apa yang terjadi seperti apa yang diharapkan termasuk di Nagari Padang Sundai. Oleh karena itu, Pemerintahan Nagari Padang Limau Sundai melakukan berbagai langkah dalam rangka mengatasi kendala yang terjadi. Adapun langkah serta upaya yang dilakukan, yaitu sebagai berikut:

1. Mengkaji Ulang Daerah Persiapan Pemekaran

Daerah persiapan tidak saja mencakup persoalan administratif semata tapi juga perlu mencakup beberapa aspek lain seperti berikut:

a. Mempersiapkan persyaratan fisik yang berkaitan dengan penataan ruang maupun batas wilayah. Di samping itu juga terumuskannya dokumen rencana tata ruang lokasi calon ibukota nagari baru hasil pemekaran maupun calon ibukota nagari induk.

b. Mempersiapkan persyaratan kelembagaan dan organisasi yang berkaitan dengan kebutuhan kantor, identifikasi aset, fungsi staf, struktur organisasi, maupun proses perencanaan dan penganggaran. Hal ini penting dilakukan dalam masa persiapan agar proses pemekaran wilayah menjadi kebutuhan bersama antara nagari induk dengan calon nagari pemekaran baru. Dengan demikian konflik tentang pengalihan aset sudah dapat dihindari sejak awal.

c. Mempersiapkan persyaratan teknis administratif yang berkaitan dengan kerjasama dengan nagari induk dan pihak ketiga yang akan melakukan pengkajian terhadap kelayakan pembentukan nagari baru hasil pemekaran.

\section{Mengekefektifkan Peran Masyarakat Sipil}

Peran masyarakat sipil harus dituangkan secara jelas untuk menentukan pilihan perlu atau tidaknya dilakukan pemekaran nagari. Dalam kaitan dengan hal ini, lembaga-lembaga atau organisasi masyarakat sipil juga harus berperan dalam memberdayakan masyarakat supaya ada pengertian yang baik tentang keuntungan dan kelemahan pemekaran nagari maupun pentingnya pelaksanaan pemekaran. Dengan demikian, dalam tahap awal atau masa persiapan, kegiatan yang harus dilaksanakan pertama kali adalah melakukan penjaringan aspirasi masyarakat. Meskipun terdapat berbagai metode penjaringan aspirasi seperti melalui quesioner, seminar atau lokakarya, namun dalam hal pemekaran wilayah nampaknya pengefektifan peran masyarakat sipil merupakan pendekatan yang paling tepat. 
3. Melakukan Pembenahan Prosedur, antara lain :

a. Pembentukan Nagari Persiapan

Pembentukan nagari persiapan dilakukan berdasarkan hasil studi kelayakan yang mencakup aspek kapasitas maupun ekonomi dengan memperhatikan kriteria-kriteria, antara lain:

1) Urutan tingkat nagari persiapan (rank) menurut besaran jumlah penduduk dibandingkan dengan nagari lainnya dalam wilayah kabupaten sebagaimana telah penulis uraikan sebelumnya;

2) Fungsi nagari di dalam sistem pusat pengembangan wilayah yang tertuang dalam RT/ RW Kabupaten;

3) Peranan ekonomi nagari di dalam lingkup yang lebih luas, yaitu kabupaten dan propinsi;

4) Kemampuan ekonomi dan besaran potensi penerimaan asli;

5) Jumlah penduduk

b. Pembangunan Nagari Persiapan

Dalam pelaksanaan selanjutnya nagari asli wajib memberdayakan nagari persiapan, dengan menempatkan pejabat yang mewakili Wali Nagari (nagari asli) di nagari persiapan, yang bertanggungjawab kepada Wali Nagari (nagari asli).

4. Meningkatkan Fasilitas serta Peningkatan Kesejahteraan Perangkat Nagari

Posisi pemerintahan nagari memegang peranan yang sangat signifikan, karena itu pemerintahan nagari harus lahir sebagai pemerintahan modern, di mana nilai-nilai demokrasi yang berlandaskan musyawarah dan mufakat menjadi identitas kepribadiannya. Karena itu, Pemerintah Kabupaten Solok Selatan jelas Bupati senantiasa memberikan dukungan dan motivasi, di antaranya melalui peningkatan kesejahteraan wali nagari dan perangkatnya.

Melalui beberapa langkah yang dikemukakan di atas, maka secara langsung akan mengurangi kendala dan memberikan solusi terhadap proses pemekaran nagari Padang Limau Sundai dari nagari induk Bidar Alam pada tahun 2009.

IV. Kesimpulan dan Saran

Kesimpulan

Berdasarkan pembahasan pada bab sebelumnya, maka penulis dapat memberikan beberapa kesimpulan sebagai berikut:

1. Secara garis besar, pemekaran Nagari Padang Limau Sundai adalah berdasarkan kepada Pasal 15 ayat (1), (2) dan (3) Peraturan Daerah Propinsi Sumatera Barat Nomor 9 Tahun 2000 tentang Ketentuan Pokok Pemerintahan Nagari, yang kemudian diganti dengan Peraturan Daerah N omor 08 Tahun 2007 tentang Pemerintahan Nagari di mana disebutkan bahwa (1) Dalam rangka efektivitas penyelenggaraan Pemerintah Nagari dan peningkatan kesejateraan masyarakat Nagari, terhadap wilayah Nagari dapat dilakukan pemekaran nagari, (2) Pemekaran Nagari 
dilakukan melalui musyawarah mufakat dengan memperhatikan keutuhan adat dan sosial budaya setempat serta keharmonisan masyarakatnya, (3) Tata cara pemekaran Nagari diatur dalam Peraturan Daerah Kabupaten.

2. Kendala dalam pemekaran Nagari Padang Limau Sundai Kecamatan Sangir Jujuan Kabupaten Solok Selatan, yaitu adanya pro dan kontra, adanya anggapan bahwa pemekaran daerah sebagai penyebab ketertinggalan, permasalahan kurangnya dana, terjadinya konflik, minimnya SDM dan fasilitas pendukung dan kurangnya partisipasi masyarakat;

3. Upaya yang dilakukan dalam rangka mengatasi kendala pemekaran Nagari Padang Limau Sundai Kecamatan Sangir Jujuan Kabupaten Solok Selatan, yaitu mengkaji ulang daerah persiapan pemekaran, mengekefektifkan peran masyarakat sipil, melakukan pembenahan prosedur, serta meningkatkan fasilitas serta peningkatan kesejahteraan perangkat nagari.

\section{Saran-Saran}

Dalam penelitian ini saran-saran yang penulis sampaikan adalah sebagai berikut:

1. Agar pembangunan di nagari bisa berjalan dan terencana dengan baik, maka Wali Nagari bersama BPN harus membuat rancangan pembangunan jangka menengah nagari (RPJMN);

2. Kepada pejabat wali nagari pemekaran, agar dapat menjalankan tugas pokok dan fungsinya dengan baik.

\section{Daftar Pustaka}

A. Gaffar, Politik Indonesia Transisi Menuju Demokrasi, Pustaka Pelajar, Yogyakarta, 2002.

Anon, Laporan Evaluasi Daerah Pemekaran, Departemen Dalam Negeri Republik Indonesia, Jakarta, 2005.

Anshar, Sayid. "PENERAPAN GAYA KEPEMIMPINAN DEMOKRATIK TERHADAP PENINGKATAN KINERJA APARATUR PADA DINAS PERHUBUNGAN, KOMUNIKASI DAN INFORMATIKA KABUPATEN KEPULAUAN MENTAWAI." (2019).

Benny Adrain, Birokrasi di Sumatera Barat; Transisi dari Tradisional ke Modern (Suatu Tinjauan Sosiologi Politik), Skripsi, Padang: Universitas Andalas, 1995.

Budi Agustono, "Otonomi Daerah dan Dinamika Politik Lokal: Studi Kasus di Kabupaten Deli Serdang, Sumatera Utara" dalam Desentralisasi Globalisasi dan Demokrasi Lokal, editor Jamil Gunawan, LP3ES, Jakarta, 2005.

Chairul Anwar, Hukum Adat Indonesia (Meninjau Hukum Adat Minangkabau), Jakarta: PT.Rineka Cipta, 1997.

Eaton, J. W, Pembangunan Lembaga dan Pembangunan Nasionl : dari Konsep ke A plikasi, UI-Press, Jakarta, 1986. 
Hadi Sabari, Struktur Tata Ruang Kota, Pustaka Pelajar, Yogyakarta, 2000

Mulia, Rizki Afri. "IN FLUENCE OF PUBLIC POLICY, PARTICIPATION OF

COMMUNITY AND EDUCATION LEVEL TO PUBLIC WELFARE

IN PADANG PARIAMAN DISTRICT." Jurnal EL-RIYASAH 10.1 (2019): 37-56.

Michael Malley, Daerah, Sentralisasi dan Perlawanan, PT Gramedia, Jakarta, 2001.

Sandjaja dan A Ibertus Heriyanto, Panduan Penelitian, Prestasi Pustakakrya, Jakarta, 2006.

Sjofjan Thalib, dkk, Studi Pelaksanaan Pemerintahan Nagari dan Efektifitasnya dalam Pelaksanaan Pemerintahan di Sumatera Barat, Balitbang Propinsi Sumatera Barat, Padang, 2002.

Sugiono, Metode Penelitian Administrasi, Alfa Beta, Bandung, 2001.

Sugiarto,dkk, Teknik Sampling, PT. Gramedia Pustaka Utama, Jakarta, 2003.

Sutami, Esensi Pembangunan Wilayah dan Penggunaan Tanah Berencana, Jurusan Geografi FMIPA-UI, Jakarta, 1989.

Undang-Undang Republik Indonesia Nomor 22 Tahun 1999 tentang Pemerintahan Daerah.

Undang-Undang Republik Indonesia Nomor 25 Tahun 1999 tentang Perimbangan Keuangan antara Pemerintahan Pusat dan Daerah.

Undang-Undang Nomor 32 Tahun 2004 tentang Pemerintahan Daerah.

Peraturan Pemerintah Republik Indonesia Nomor 84 Tahun 2000 tentang Pedoman Organisasi Perangkat Daerah.

Peraturan Pemerintah Republik Indonesia Nomor 129 Tahun 2000 tentang Persyaratan Pembentukan dan Kriteria Pemekaran, Penghapusan dan Penggabungan Daerah.

Peraturan Pemerintah Republik Indonesia Nomor 8 Tahun 2003 Pedoman Organisasi Perangkat Daerah. 